\title{
Amino acids digestibility of pelleted microparticle protein of fish meal and soybean meal in broiler chickens
}

\author{
N. Suthama ${ }^{1}$,* and P. J. Wibawa ${ }^{2}$ \\ ${ }^{1}$ Department of Animal Science, Faculty of Animal and Agricultural Sciences, Diponegoro University, \\ Tembalang Campus, Semarang 50275 - Indonesia \\ ${ }^{2}$ Department of Chemistry, Faculty of Science and Mathematics, Diponegoro University, \\ Tembalang Campus, Semarang 50275 - Indonesia \\ *Corresponding E-mail: nsuthama@gmail.com
}

Received December 26, 2017; Accepted February 27, 2018

\begin{abstract}
ABSTRAK
Sumber protein yang umum untuk unggas, tepung ikan dan bungkil kedelai, digiling untuk memperkecil ukuran partikel. Bahan yang sudah digiling selanjutnya dilarutkan dengan air suling $(1: 4$ $\mathrm{b} / \mathrm{v}$ ) dengan ditambah $2 \mathrm{~mL}$ virgin coconut oil untuk setiap $500 \mathrm{~mL}$ larutan sebelum diproses dengan ultrasound transducer (ultrasonic bath) untuk memperoleh protein partikel mikro. Penurunan ukuran partikel protein merupakan satu cara yang dapat meningkatkan penggunaan protein pada unggas. Sebanyak 180 ekor broiler digunakan untuk uji force feeding dan dan 10 ekor lainnya untuk koreksi endogenus pada saat ayam berumur 1,5 bulan (45 hari). Protein mikropartikel tepung ikan dan bungkil kedelai dalam bentuk mash dan pellet diuji secara terpisah dan dibandingkan dengan protein asli masing-masing. Rancangan acak lengkap dengan 3 perlakuan (bentuk asli, mash, pellet) dan 6 ulangan (@10 ekor) digunakan untuk masing-masing partikel bahan. Kecernaan protein dan asam amino esensial, dan retensi kalsium (Ca) merupakan parameter yang diamati. Analisis variansi dan uji Duncan digunakan untuk analisis data. Pellet protein mikropartikel tepung ikan dan bungkil kedelai masingmasing menghasilkan kecernaan protein dan asam amino, dan retensi Ca nyata $(\mathrm{P}<0,05)$ paling tinggi, meskipun ditemukan sedikit asam amino dengan kecernaan lebih rendah pada kedua bahan bentuk mash. Kesimpulan bahwa bentuk pellet protein mikropartikel tepung ikan dan bungkil kedelai meningkatkan kecernaan protein dan asam amino, dan retensi Ca pada broiler.
\end{abstract}

Kata kunci: broiler, bungkil kedelai, kecernaan asam amino, protein mikropartikel, tepung ikan

\begin{abstract}
Commom protein sources for poultry, fish meal and soybean meal, were ground to obtain reduced particle size. The particle was then dissolved in distilled water $(1: 4 \mathrm{w} / \mathrm{v})$, and added with $2 \mathrm{~mL}$ virgin coconut oil for every $500 \mathrm{~mL}$ solution prior to ultrasound transducer (ultrasonic bath) treatment to obtain protein microparticle. Reducing particle size is one possible way to increase protein utilization. 180 birds were used for forced feeding and 10 other birds were plotted for endogenous correction, when they were one month and a half old. Microparticle protein of both ingredients were tested separately in either mash or pelleted forms and compared to intact protein. Completely randomized design with 3 treatments (intact, mash, and pellet) and 6 replications (10 bidrs each) was arranged for the respective ingredient. Protein and essential amino acid digestibilities, and calcium retention were the parameters measured. Analysis of variance continued to Duncan test were applied to statistically evaluate the data. Pelleted microparticle protein of fish meal and soybean meal, respectively, resulted in significantly $(\mathrm{P}<0.05)$
\end{abstract}


highest protein and amino acids digestibilities, and Ca retention although lower disgestibility of fewer amino acids was found in mash form. In conclusion, pelleted form of microparticle protein of either fish meal or soybean meal improve protein and mostly amino acids digestibilities, and calcium retention in broiler.

Keywords: broiler, soybean meal, amino acid digestibility, microparticle protein, fish meal

\section{INTRODUCTION}

In relation to poultry feed technology for higher achievement of productive efficiency, some illustration concerning the physically particle size of feed in general are provided as a comparison prior to describing protein microparticle in particular. It have been reported previously elsewhere (Amerah et al., 2008; Svihus, 2011) that particle size was correlated with gizzard development and digestive activity. Large particles of mash diet promoted broiler performance (Amerah et al., 2007b), but the effect of particle size on performance was controversial when pelleted diets were fed. Jacobs et al. (2010) reported that apparent metabolizable energy (AMEn) and weight gain of 21-day-old broilers were lowered by feeding diets containing corn with particle size more than $1387 \mu \mathrm{m}$. However, Amerah et al. (2007a) did not observe any differences of either AMEn or digesta passage rate between birds given diets formulated with medium $(3 \mathrm{~mm})$ or coarse $(7 \mathrm{~mm})$ particle size. The effect of particle size may be related to the type of feedstuff evaluated. Ganzer et al. (2007) observed that reduction in amino acid digestibility by $6.3 \%$ in diets formulated with finely-ground corn $(0.62 \mathrm{~mm})$ compared to coarsely ground corn $(0.96 \mathrm{~mm})$.

However, since the increase in price of dietary protein sources both fish meal and soybean meal has forced poultry nutritionist to find an alternative way to improve nutrients utilization efficiency. Reduction of particle size provides some advantages in nutrients utilization and efficiency to support productivity of growing poultry. Particle size reduction bring about the increase in both the number of particles and the surface area per unit volume allowing greater access to digestive enzymes (Huang and Stein, 2016). The interest in dietary protein particle size has increased due to the economical purposes of optimizing protein utilization and improving poultry production efficiency. Special concern in the present study was focused on the processing procedure of proteins of fish meal and soybean meal. Fish meal and soybean meal are the two common protein sources in poultry feeding. Fish meal as animal protein source is produced from different types and varieties of fish and may caused much variation of protein and amino acid contents. When fish meal was not properly stored, its protein content can be broken down and resulting biogenic amines such as histamine at higher level, and may caused gizzard erosion in chickens (Jacob, 2013). In case of soybean meal, the limitation use for poultry is associated with the imbalance essential amino acids content and high in trypsin inhibitor level. (Zollitsch et al., 1993; Zhu et al., 1996;). Processing can markedly influence the digestibility of amino acids in soybean meal due to reduced trypsin inhibitor. Soybean meal is known to be rich source of lysine, tryptophan, threonine, isoleucine, and valine, but containing low sulfuric amino acids, such as methionine and cystine (Banaszkiewicz, 2011).

Producing protein microparticle obtained from fish meal and soybean meal by transducer ultrasound treatment is the way to fulfill the purpose of improving protein and/or amino acids utilization. However, in relation to the degree of particle size, the birds may encountered difficulties in consuming very course or very fine particles (Pacheco et al., 2013), thus pelleting would be a solution can be applied when feeding microparticle protein. It was previously reported that the better performance of broilers fed pelleted diets relative to those fed mash diets is well known in poultry production (Amerah et al., 2007b; Dozier et al., 2010). The result is associated with the higher dietary density and better digestibility due to changes in feed physical form resulting from processing, and reduced feed waste and increased energy efficiency. Zang et al. (2009) indicated that better performance of broilers receiving pelleted feeds is associated with the higher AME availability, better protein digestibility, as well as improved intestinal function. Performance improvement due to pelleting is more evident in fast growing poultry. For example, pellet length between 2.5 and 3.0 $\mathrm{mm}$ could be categorized as appropriate size in relation to growth and feed conversion in broiler 
starters (Quentin et al., 2004; Cerrate et al., 2009; Abdollahi and Ravindran. 2013). However, pellet size with either 5 or $7 \mathrm{~mm}$ in length was reported to be suitable for broiler finishers (Abdollahi and Ravindran. 2013). Pelleting compensates the effects of dietary small particle sizes, because of particle size distribution need to be uniform, and reduced energy expenditure during digestion. Therefore, the present study was conducted to evaluate microparticle protein derived from fish meal and soybean meal in the forms of pellet and mash compared to intact sources.

\section{MATERIALS AND METHODS}

\section{Microparticle Protein Preparation}

Fish meal and soybean meal, as common protein sources for poultry, with their chemical composition and amino acid contents (Table 1) were ground to obtain reduced particle size. A slightly modified method of Jambrak et al. (2014) was adopted to obtain microparticle protein. The intact particle was then dissolved in distilled water with the ratio of $1: 4(\mathrm{w} / \mathrm{v})$, and it was further added with $2 \mathrm{~mL}$ virgin coconut oil for every $500 \mathrm{~mL}$ solution prior to ultrasound transducer or ultrasonic bath treatment (Power Sonic 405, Hwashin Techonoly Co., Korea). The ultrasonic bath treatment with the system of sound wave from the transducer radiate to the liquid at $40 \mathrm{~Hz}$ was run for $60 \mathrm{~min}$ to obtain protein particle dispersion. In order to avoid protein damage in paricular, solid component was firstly oven-dried at $40^{\circ} \mathrm{C}$, and continued to sun-dried. Particle size determination was performed using particle size analyzer equipment (Nano Particle Analyzer SZ100, Horiba Ltd., Japan), and particle size detected in average was 1.213 and 0.426 microns for fish meal and soybean meal, respectively.

\section{Experimental Animal and Design}

A total of 190 birds of one-day old sexed broiler of Lohman strain, with equal amount of male and female, were kept at a brooder cage prior to feeding microprotein test ingredient. When the birds were 21-day old they were allocated into individual cage (battery) by deviding into 2 criterions, namely 180 birds were used for forced feeding and 10 other birds were plotted and fasted for endogenous correction. Forced feeding procedure was performed when the birds were one and a half month old (45-day old) with body weight of $2475.5 \pm 302.1 \mathrm{~g}$. A completely randomized design with 3 treatments (intact, mash, and pellet) and 6 replications (10 birds each, 5 males and 5 females) was arranged in the present study for the respective protein source, namely fish meal and soybean meal. Microparticle protein of fish meal and soybean meal were tested separately in either mash or pelleted forms and compared to their intact protein.

\section{Parameter and Statistical Analysis}

Parameters measured were digestibilities of protein and selected essential amino acids (8 amino acids), and calcium (Ca) retention. Digestibilities of protein and amino acids, and $\mathrm{Ca}$ retention were measured based on wet forced feeding method adopted from the simply modified procedure of Lessire (1990). Each bird was force fed with approximately $50 \mathrm{~g}$ air dry tested ingredient that was moistened first with distilled water with the ratio of $1: 2(\mathrm{w} / \mathrm{v})$. Birds were fasted for $24 \mathrm{~h}$ to completely emptying the digestive tracts prior to forced feeding was performed. Fecal digestibilities of protein and amino acids, and $\mathrm{Ca}$ retention as well were calculated from the totally collected excreta. Digestibilities of protein (Pr) and amino acid (AA) were corrected with respective endogenous value obtained from group of fasting birds with the following formula (McNab, 1994) :

Pr or AA digestibility $(\%)=[[\mathrm{PrC}$ or AAC $-(\operatorname{PrE}$ or AAE - Epr or EAA)]/[PrC orAAC] x 100 ... (1)

Where:

$\mathrm{PrC}=$ protein consumed

AAC $=$ amino acid consumed

$\mathrm{PrE}=$ protein in excreta

$\mathrm{AAE}=$ amino acid in excreta

$\mathrm{EPr}=$ endogenous protein

EAA $=$ endogenous amino acid

Calcium (Ca) retention was calculated according to the formula for mineral retention in general (Thomas and Ravindran, 2010) with slight modification as follows:

Ca retention $(\%)=[(\mathrm{Ca}$ consumed $-\mathrm{Ca}$ excreta $) /$

Ca consumed]/ 100

Data were subjected to statistical procedure of analysis of variance to evaluate treatments effect. When the treatment showed significant effect, it was continued to Duncan test (Steel and Torrie, 1981) to determine the difference between 
Table 1. Chemical Composition and Amino Acid Contents of Fish Meal and Soybean Meal

\begin{tabular}{lcc}
\hline \multirow{2}{*}{ Nutritional parameters } & \multicolumn{2}{c}{ Ingredients } \\
\cline { 2 - 3 } & $\begin{array}{c}\text { Fish } \\
\text { Meal }\end{array}$ & $\begin{array}{c}\text { Soybean } \\
\text { Meal }\end{array}$ \\
\hline Cemical compositions* & & \\
$\quad$ Crude protein & 42.14 & 40.77 \\
$\quad$ Ether extract & 12.47 & 19.54 \\
$\quad$ Crude fiber & 1.85 & 3.02 \\
$\quad$ Ash & 24.11 & 5.08 \\
$\quad$ Calcium (Ca) & 4.20 & 0.35 \\
Phosphorus (P) & 2.92 & 0.57 \\
Amino acid contents* & & \\
Arginine & 3.65 & 2.01 \\
Isoleucine & 2.36 & 1.15 \\
Leucine & 3.66 & 2.03 \\
Lysine & 2.58 & 1.83 \\
Methionine & 1.33 & 0.54 \\
Phenylalanine & 3.11 & 1.51 \\
Threonine & 1.37 & 1.06 \\
Valine & 2.73 & 1.62 \\
\hline
\end{tabular}

*Laboratory analysis value (2017)

mean values.

\section{RESULTS AND DISCUSSION}

Protein and amino acid digestibilities, and calcium $(\mathrm{Ca})$ retention in either pelleted microparticle protein of fish meal (Table 2) or soybean meal (Table 3 ) significantly increased. In contrast, some amino acid digestibilities such as arginine, isoleucine, phenylalanine, and threonine of mash microparticle protein of fish meal were significantly $(\mathrm{P}<0.05)$ lower than those of intact and pelleted forms (Table 2). Similar case was also found in mash microparticle portein of soybean meal for isoleucine, lysine, phenylalanine, and valine digestibilities (Table 3). In general, protein and amino acid digestibilities, and also $\mathrm{Ca}$ retention of pelleted microparticle protein of fish meal and soybean meal indicated the highest values as compared to other forms.

Protein digestibility of mash form of both ingredients did not also better than that of intact protein. There was no improvement in digestibilities of protein as well as some amino acids of mash formed ingredient is possibly due to the unbound fine particle which caused very fast away from the gastrointestinal tract. However, pelleted diets are assumed to have longer spent time in the intestine. It was reported previously that the better performance of broilers fed pelleted diets compared to those fed mash diets is well known in poultry production (Amerah et al., 2007b; Dozier et al., 2010). In other side, it has been reported elsewhere that the smaller particle size of either feed ingredients in general (Gabriel et al., 2003; Amerah et al., 2007a; 2008; Chewning et al., 2012) or protein in particular (Jambrak et al., 2014; Huang and Stein, 2016) allowing the greater access to digestive enzymes which then increased nutrients digestibility. Reduce particle size of protein with pelleted form would be the best choice as applied for poultry by considering that birds may encounter difficulties in consuming very course or very fine particles of feed. Decreasing particle size could improve the $\mathrm{DE}$ and $\mathrm{ME}$ of wheat in finishing pigs (Fan et al., 2017), and pelleted corn particle size increased growth peformance in growing broilers (Parsons et al., 2006). Zang et al. (2009) indicated that better performance of broilers receiving pelleted feeds is associated with the higher AME availability, better protein digestibility, as well as better intestinal function. Pelleting compensates the effects of dietary small particle sizes, because the frequency of particle size distribution is uniform and energy expenditure is reduced during digestion. The more efficiency of pelleted diet has been proved by Suthama and Wibawa (2017), that the increased protease activity could be associated with higher protein digestibility in pelleted-diet fed broiler.

The higher nutrients digestibility of pelleted fish meal can be associated with protein particle size was 3 to 4 fold larger than soybean meal (Suthama and Wibawa, 2016), and related to chemical properties. The differences in results between fish meal and soybean meal is assumably due to the presence of phytate component such as oligosaccharide and anti-trypsin in soybean meal. The inferior results found for soybean meal was seemingly attributable to the presence of phytate compound (Banaszkiewicz, 2011; Tahir et al., 2012), non-protein soluble component such as oligosaccharide (Kocher et al., 2002; Oliveira and Stein, 2016), and trypsin inhibitor 
Table 2. Protein and Essential Amino Acids Digestibilities of Microparticle Protein Derived from Fish Meal in Broiler Chicken

\begin{tabular}{lccc}
\hline \multirow{2}{*}{ Parameter } & Intact protein & \multicolumn{2}{c}{ Microparticle protein } \\
\cline { 3 - 4 } & & Mash & Pellet \\
\hline Fish Meal & $81.4^{\mathrm{b}}$ & $82.8^{\mathrm{b}}$ & $87.0^{\mathrm{a}}$ \\
Protein digestibility (\%) & & & \\
Amino acids digestibility (\%) & $78.0^{\mathrm{b}}$ & $75.6^{\mathrm{c}}$ & $84.9^{\mathrm{a}}$ \\
Arginine & $86.4^{\mathrm{b}}$ & $84.0^{\mathrm{c}}$ & $88.8^{\mathrm{a}}$ \\
Isoleucine & $87.2^{\mathrm{a}}$ & $85.5^{\mathrm{b}}$ & $88.1^{\mathrm{a}}$ \\
Leucine & $76.9^{\mathrm{b}}$ & $77.7^{\mathrm{b}}$ & $81.7^{\mathrm{a}}$ \\
Lysine & $77.3^{\mathrm{b}}$ & $75.0^{\mathrm{b}}$ & $88.4^{\mathrm{a}}$ \\
Methionine & $65.5^{\mathrm{a}}$ & $63.7^{\mathrm{b}}$ & $66.3^{\mathrm{a}}$ \\
Phenylalanine & $82.4^{\mathrm{a}}$ & $78.0^{\mathrm{b}}$ & $81.6^{\mathrm{a}}$ \\
Threonine & $77.4^{\mathrm{b}}$ & $76.9^{\mathrm{b}}$ & $81.0^{\mathrm{a}}$ \\
Valine & $62.9^{\mathrm{b}}$ & $63.3^{\mathrm{b}}$ & $69.1^{\mathrm{a}}$ \\
Ca retention (\%) & & & \\
\hline
\end{tabular}

${ }^{\mathrm{a}-\mathrm{c}}$ Mean values within row followed by different superscripts are significantly different $(\mathrm{P}<0.05)$

(Banaszkiewicz, 2011; Pacheco et al., 2013). Phytate compound in soybean meal has been reported to be varied with the range of betwen 1 and $1.5 \%$ (Banaszkiewicz, 2012). Phytic acid may provide some advantages in binding affinity for calcium and protein which is beneficial in tofumaking, but this reactive mechanism has adverse effect on $\mathrm{Ca}$ and protein absorption in monogastric animals, ecpecially poultry. This phenomenon might be proved by the data of $\mathrm{Ca}$ retention and protein digestibility of pelleted soybean meal (Table 3) were lower than those of similar form of fish meal (Table 2), although it has been treated with ultrasound transducer. Thus, longer ultrasound transducer treatment is needed for soybean meal to maximize nutrients utilization. Soluble carbohydrates and trypsin inhibitor can interfere with protein and/or amino acids utilization, therefore, protein and some amino acids digestibilities were still lower for soybean meal.

The present results can also be connected with the digestive enzyme activity which was spesific for protein and a certain amino acid (Krehbiel and Matthews, 2003; Ren et al., 2014).
It may be comparable with the report of Suthama et al. (2014) indicated that nitrogen $(\mathrm{N})$ retention was improved without any change in intestinal protease activity although with different dietary protein content. This implied that the work of intestinal protease depended on the protion of ingredients-containing non protein soluble carbohydrate used in the diet. In some cases, digestibility of individual amino acid is found to be similar pattern to that of protein, and other phenomenon indicates that higher protein digestibility is not always followed by similar level of individual amino acid digestibility. Similar report by Ravindran (2013) that a given substrate or nutrient of a certatin feedtuff was not completely the same as found in other ingredient. Therefore, similar nutrient of the different ingredient showed the different response to digestive enzyme. It was supported by the finding of Moughan et al. (2014) that the variation of individual amino acid digestibility was smaller among grains or its by products. A comparisson of individual amino acid digestibility between animal protein sources, blood meal and fish meal, are the interesting example. Blood meal has 
Table 3. Protein and Essential Amino Acids Digestibilities of Microparticle Protein Derived from Soybean Meal in Broiler Chicken

\begin{tabular}{lccc}
\hline \multirow{2}{*}{ Parameter } & Intact protein & Mash & Pellet \\
\cline { 3 - 4 } $\begin{array}{l}\text { Soybean meal } \\
\text { Protein digestibility (\%) }\end{array}$ & $80.6^{\mathrm{b}}$ & $82.0^{\mathrm{b}}$ & $86.1^{\mathrm{a}}$ \\
Amino acids digestibility (\%) & & & \\
$\quad$ Arginine & $80.0^{\mathrm{b}}$ & $79.4^{\mathrm{b}}$ & $88.8^{\mathrm{a}}$ \\
$\quad$ Isoleucine & $74.8^{\mathrm{a}}$ & $69.4^{\mathrm{b}}$ & $73.8^{\mathrm{a}}$ \\
Leucine & $81.8^{\mathrm{c}}$ & $84.5^{\mathrm{b}}$ & $89.7^{\mathrm{a}}$ \\
Lysine & $81.0^{\mathrm{a}}$ & $75.0^{\mathrm{b}}$ & $79.6^{\mathrm{a}}$ \\
Methionine & $61.1^{\mathrm{b}}$ & $62.0^{\mathrm{b}}$ & $69.3^{\mathrm{a}}$ \\
Phenylalanine & $79.2^{\mathrm{a}}$ & $76.6^{\mathrm{b}}$ & $80.3^{\mathrm{a}}$ \\
Threonine & $73.8^{\mathrm{c}}$ & $78.6^{\mathrm{b}}$ & $86.3^{\mathrm{a}}$ \\
$\quad$ Valine & $71.8^{\mathrm{b}}$ & $67.4^{\mathrm{c}}$ & $77.9^{\mathrm{a}}$ \\
Ca retention (\%) & $56.2^{\mathrm{b}}$ & $55.9^{\mathrm{b}}$ & $60.2^{\mathrm{a}}$ \\
\hline
\end{tabular}

${ }^{\mathrm{a}-\mathrm{c}}$ Mean values within row followed by different superscripts are significantly different $(\mathrm{P}<0.05)$

higher amino acid digestibility with smaller variation than fish meal. This provides the important meaning that fish meal has large variation for individual amino acid digestibility.

\section{CONCLUSION}

It can be concluded that pelleted form of either fish meal or soybean meal improve protein and amino acids digestibilities, and $\mathrm{Ca}$ retention in broiler, although some individual amino acids digestibility of mash form decrease.

\section{ACKNOWLEDGMENTS}

The authors wish to express immeasurable thanks to the Ministry of Research, Technology and Higher Education, Indonesia via Rector of Diponegoro University for financial support (Letter of assignment No. 27823/UN7.5.1/PG/2017) of this work which made a part of the data are possible to be published in this journal.

\section{REFERENCES}

Abdollahi, M.R. and V. Ravindran. 2013. Influence of pellet length on pellet quality and performance of broiler starters. Appl. Poult. Res. 22(3): 516 - 522.

Amerah, A.M., V. Ravindran, R.G. Lentle and D.G. Thomas. 2007a. Influence of feed particle size and feed form on the performance, energy utilization, digestive tract development, and digesta parameters of broiler starters. Poult. Sci. 86(12): 26152623.

Amerah, A.M., V. Ravindran, R.G. Lentle and D.G. Thomas. 2007b. Feed particle size: Implications on the digestion and performance of poultry. World's Poult. Sci. J. 63(03):439-455.

Amerah, A.M., V. Ravindran, R.G. Lentl, and D.G. Thomas. 2008. Influence of feed particle size on the performance, energy utilization, digestive tract development, and digesta parameters of broiler fed wheatand corn-based diets. Poult. Sci. 87(11): 
2320-2328.

Banaszkiewicz, T. 2011. Nutritional Value of Soybean Meal. In: Soybean and Nutrition (A. H. El-Shemy, ed.). INTECH Open Acces Pub. Rijeka, Croatia. P. $1-20$.

Cerrate, S, Z. Wang, C. Coto, F. Yan and P.W. Waldroup. 2009. Effect of pellet diameter in broiler starter diets on subsequent performance. J. Appl. Poult. Res. 18(3): 590-597.

Chewning, C.G., C. R. Stark and J. Brake. 2012. Effects of particle size and feed form on broiler performance J. Appl. Poult. Res. 21(4): 830-837.

Dozier, W.A., K.C. Behnke, C.K. Gehring and S.L. Branton. 2010. Effects of feed form on growth performance and processing yields of broiler chickens during a 42-day production period. J. Appl. Poult. Res. 19(3): 219-226.

Fan, Y., P. Guo, Y. Yang, T. Xia, L. Liu and Y. Ma. 2017. Effects of particle size and adaptation duration on the digestible and metabolizable energy contents and digestibility of various chemical constituents in wheat for finishing pigs determined by the direct or indirect method. Asian-Aust. J. Anim. Sci. 30(4): 554-561.

Gabriel, I., S. Mallet and M. Leconte. 2003. Differences in the digestive tract characteristics of broiler chickens fed on complete pelleted diet or on whole wheat added to pelleted protein concentrate. $\mathrm{Br}$. Poult. Sci. 44(2):283-290.

Ganzer, C., H. Kluth, and M. Rodehutscord. 2007. Effect of particle size on precaecal digestibility of amino acids from maize and soybean meal in broilers. World Poultry Science Association. Proc. the $16^{\text {th }}$ European Symposium on Poultry Nutrition, Strasbourg. P. 459-462.

Huang, C. and H.H. Stein. 2016. Amino acid digestibility in soy protein concentrate with different particle sizes fed to weanling pigs. Pig Progress Res. Report. P. $32-33$

Jacob, J. 2013. Including Fishmeal in Organic Poultry Diets. Organic Agriculture. A Part of the Cooperative Extension System.

Jacobs, C.M., P.L. Utterback and C.M. Parson. 2010. Effects of corn particle size on growth performance and nutrient utilization in young chicks. Poult. Sci. 89(3):539-544.

Jambrak, A.R., T.J. Mason, V. Lelas, L. Paniwnyk and Z. Herceg. 2014. Effect of ultrasound treatment on particle size and molecular weight of whey proteins. J. Food Eng. 121: 15-23.

Kocher, A., M. Choct, M.D. Porter, and J. Broz. 2002. Effects of feed enzymes on nutritive value of soybean meal fed to broilers. Br. Poult. Sci. 43(1):54-63.

Krehbiel, C.R., and J.C. Matthews. 2003. Absorption of Amino Acids and Peptides. In: Amino Acids in Animal Nutrition (J.P.F. D'Mello ed.). $2^{\text {nd }} E d$. CAB International, Kentucky. P. 41-70.

Lessire, I. 990. Effect of the feeding technique: ad libitum, dry or wet force feeding on the metabolizable energy value of raw materials for poultry. Br. Poult. Sci. 31:785743.

Moughan, P.J., V. Ravindran, and J.O.B. Sorbara. 2014. Dietary protein and amino acidsConsideration of the undigestible fraction. Poult. Sci. 93(9):2400-2410.

McNab, J.M. 1994. Amino Acid Digestibility and Availability Studies with Poultry. In: Farm Animal Nutrition (J.P.F. D'Mello ed.). CAB International. P. 185-203.

Oliveira, M.S. and H.H. Stein. 2016. Digestibility of energy, amino acids, and phosphorus in a novel source of soy protein concentrate and in soybean meal fed to growing pigs. J. Anim. Sci. 94(8): 3343-352.

Pacheco, W.J., C.R. Stark, P.R. Ferket, and J. Brake. 2013. Evaluation of soybean meal source and particle size on broiler performance, nutrient digestibility, and gizzard development. Poult. Sci. 92(11): 2914-2922.

Parsons, A.S., N.P. Buchanan, K.P. Blemings, M.E. Wilson, and J.S. Moritz. 2006. Effect of corn particle size and pellet texture on broiler performance in the growing phase. J. Appl. Poult. Res. 15(2):245-255.

Quentin, M., I. Bouvarel, and M. Picard. 2004. Short- and long-term effects of feed form on fast- and slow-growing broilers. J. Appl. Poult. Res. 13(4):540-548.

Ravindran, V. 2013. Feed enzymes: The science, practice, and metabolic realities. J. Appl. Poult. Res. 22(3) :628-636.

Ren, L.Q., F. Zhao, H.Z. Tan, J.T. Zhao, J.Z. Zhang, and H.F. Zhang. 2014. Effects of dietary protein source on the digestive enzyme activities and electrolyte composition in the small intestinal fluid of chickens. Poult. Sci. 91(7):1641-1646. 
Steel, R.G.D. and J. H. Torrie. 1981. Principles and Procedures of Statistics: A Biometrical Approach. McGraw-Hill Book Company, New York, Toronto, London.

Suthama, N., H.I. Wahyuni, and B. Sukamto. 2014. Protein deposition and protease activity in growing Kedu chicken fed improved diet. Proc. The $16 \mathrm{t}^{\mathrm{h}}$ Asia Austrasian Animal Production Congress. 10-14 November 2014, Yogyakarta, Indonesia

Suthama, N., and P.J. Wibawa. 2016. Digestibility evaluation of microparticle protein derived from fish meal and soybean meal in broiler chicken. Proc. The $3^{\text {rd }}$ Animal Production International Seminar ( $3^{\text {rd }}$ APIS) and The $3^{\text {rd }}$ ASEAN Regional Conference on Animal Production (3rd ARCAP). Shining city of Batu, Indonesia, October 19-21, 2016.

Suthama, N., and P.J. Wibawa. 2016. Feeding microparticle protein-composed diet on protease activity and protein utilization in broiler chickens. Proc. The Sixth International Conference in Sustainable Animal Agricultural for Developing Countries (The $6^{\text {th }}$ SAADC 2017). Shining city of Batu, Indonesia, October 16-19, 2017.

Svihus, B. 2011. The gizzard:function, influence of diet structure and effects on nutrient availability. World's Poult. Sci. J. 67(2): 207-224.

Tahir, M., M.Y. Shim, N.E. Ward, C. Smith, E. Foster, A.C. Guney, and G.M. Pesti. 2012. Phytate and other nutrient components of feed ingredients for poultry. Poult. Sci. 91(4):928-935.

Thomas, D.V., and V. Ravindran. 2010. Mineral retention in young broiler chicks fed diets based on wheat, sorghum or maize. AsianAust. J. Anim. Sci. 23(1):68-73.

Zang, J.J., X.S. Piao, D.S. Huang, J.J. Wang, X. MA, and Y.X. MA. 2009. Effects of feed particle size and feed form on growth performance, nutrient metabolizability and intestinal morphology in broiler chickens. Asian-Aust. J. Anim. Sci. 22(1):107-112.

Zhu, S., M.N. Raiz and E.W. Lusas. 1996. Effect of different extrusion temperatures and moisture content on lipoxygenase inactivation and protein solubility in soya beans. J. Agric. Food Chem. 44(10): 33153318.

Zollitsch, W., W. Wetscherek and F. Lettner. 1993. Use of differently processed full fat soya beans in a diet for pig fattening. Anim. Feed Sci. Technol. 41(3):237-246. 